\title{
PROTECTION OF PRIVILEGES AND IMMUNITIES \\ OF UNITED STATES CITIZENS AGAINST INTERFERENCE BY INDIVIDUALS
}

The cause of civil rights received a new impetus in an almost unforeseen direction in 1950 by way of a new interpretation of an old statute. In the case of Hardyman $v$. Collins, ${ }^{1}$ the Court of Appeals for the Ninth Circuit, in the majority opinion by Judge Orr, interpreted sec. 2 (3) of the Civil Rights Act of $1871^{2}$ as giving a federal cause of action for damages against individuals who deprived the plaintiffs of certain privileges of United States Citizens.

In the principal case, the plaintiffs were members of the Crescenta-Canada Democratic Club, an affiliate of the Democratic Party of Los Angeles County, California, and were holding a meeting for the avowed purpose of discussing the Marshall Plan and for sending a petition to the President and to various members of Congress expressing their opposition to the plans. Defendants, members of the American Legion, allegedly conspired to break up the meeting and thus prevented transmission of the proposed resolution, and did several acts in furtherance of this conspiracy.

${ }^{2}$ Hardyman v. Collins, 183 F.2d 308 (9th Cir.) (1950), cert. granted 19 L.W. 3085 (Oct. 9, 1950).

217 Stat. 13, codifled in 8 U.S.C. sec. 47 (3): "If two or more persons in any State or Territory conspire or go in disg ise on the highway. or on the premises of another, for the purpose of depriving, either directly or indirectly, any person or class of persons of the equal protection of the laws, or of equal privileges and immunities under the laws; or for the purpose of preventing or hindering tie corstituted anthorities of any State or Territory from giving or securing to all persons within such State or Territory the equal protection of the laws; or if two or more persons conspire to prevent by force, intimidation, or threat, ang citizen who is lawfully entitled to vote; from giving his support or advocacy in a legal manner, to or in favor of the election of any lawfully qualifled person as an elector for President or Vice President, or as a member of Congress of the United States; or to injure any citizen in person or property on account of such advocacy; in case of conspiracy set forth in this section, if one or more persons engaged therein do, or cause to be done, any act in furtherance of the object of such conspiracy, whereby another is injured in his person or property, or deprived of havlng and exercising any right or privilege of a citizen of the United States, the party so injured or deprived may have an action for the recovery of damages, occasioned by such injury or deprivation, against any one or more of the conspirators." 
Among the acts charged were entering the building where the meeting was taking place and, with force and threats of violence, dispersing the persons attending, whereby the plaintiffs allegedly were precluded from adopting the resolution-and thus deprived of their constitutional right as citizens of the United States to petition the President and the Congress for redress of grievances.

The District Court dismissed the complaint for failure to state a federal cause of action, on the ground that recovery under section 2 (3) of the Civil Rights Act demands that the acts be done under color of law. $^{3}$ The dismissal was reversed in the Court of Appeals, which held that the acts alleged came within the statute. 4 Judge Healy dissented, arguing that the District Court was correct in its interpretation of the statute, and adding that the construction placed on the statute by the majority rendered even the constitutionality of the statute somewhat dubious."

The four major questions involved in determining the proper outcome of this case seems to be:

I. Does Congress have the power to protect rights "inherent in national citizenship" by authorizing a civil action against individuals who deprive citizens of their rights?

II. If so, is the right to assemble te petition Congress for redress of grievances within this category of rights?

III. Did Congress exercise this power in enacting sec. 2 (3) of the Civil Rights Act of 1871, and if so, what situations did it intend to cover.

IV. If Congress intended to protect against individual action rights guaranteed only by the Fourteenth Amendmen as well as those "inherent in national citizenship," is the section unconstitutional as being too broad and inseparable?

\section{The Power of Congress}

In the early decades after the adoption of the Fourteenth

- Hardyman v. Collins, 80 F.Supp. 601 (S. D. Cal. 1949).

- See note 1, supra.

Id. at p. 314.

- United States v. Cruikshank, 92 U.S. 542 (1875). 
Amendment, it was established by the Cruikshank, ${ }^{6}$ Harris, ${ }^{7}$ and Civil Rights ${ }^{8}$ cases that the Amendment gave Congress power to protect the rights guaranteed therein only against state action, and this doctrine is now well established. The Fourteenth Amendment, however, is not the basis on which the majority in the Court of Appeals decision rely in their argument for upholding the constitutionality of the statute. Judge Orr does not rest his argument that Congress has the power to enact such statute on any particular section of the Constitution other than to say that he does base it on the Constitution as it existed prior to the adoption of the Fourteenth Amendment. He apparently bases his conclusion on the fact that the United States is a sovereign nation with a republican form of government; therefore, it must protect, against whatever might destroy them, those rights of citizens which are necessary for the proper functioning of the Republic.

That Congress has the power to protect certain rights of citizens against deprivation by individuals is a well established doctrine that dates back to a period before the Fourteenth Amendment. In 1867, a federal right of access to the nation's capital was recognized and protected by the Supreme Court. Although the 1867 decision held that a state could not infringe this right, only the Fourteenth Amendment requires state action, and that amendment was not in existence at the time. ${ }^{\theta}$ This doctrine has since been expounded by the numerous cases applying sec. 241 of the Criminal Code, ${ }^{10}$ which makes it a criminal offense for two or more persons to conspire or to go in disguise on the highways, or on another's premises 'to injure, oppress, threaten, or intimidate any citizen in the free exercise or enjoyment of any right or privilege secured to him by the Constitution or laws of the United States ..."10 This "right or privilege" has been held to include the right to be secure in one's person while in the custody of a United States Mar-

United States v. Harris, 106 U.S. 629 (1882).

- Civil Rights Cases, 109 U.S. 327 (1883).

- Crandall v. Nevada, 6 Wall. 35 (1867).

Io 18 U.S.C. sec. 241 , a codification of the criminal portion of sec. 2 of the Civil Rights Act of 1871 (17 8tat. 13). 
shal, 11 the right to inform a marshal of a violation of federal law, ${ }^{12}$ and the right to vote in federal elections. ${ }^{18}$ The right peaceably to assemble is protected against state action, ${ }^{14}$ but not against individual action, ${ }^{15}$ at least, unless the assembly is for a federal purpose, a possibility to be discussed later. ${ }^{16}$

In view of the interpretations and applications of the criminal statute discussed above, Congress undoubtedly has the power to enact a statuto imposing civil liability as to the rights already protected by criminal sanctions.

\section{Inherent Right To Petition Congress}

It has been held that the right peaceably to assemble is an incident of stato citizenship, not of federal, and therefore the federal government lacks the power to protect this right against individual action, ${ }^{17}$ although; under the Fourteenth Amendment, it can protect the right against action taken under color of state law. ${ }^{18}$. Does the fact that the purpose of the assembly was to potition Congress for redress of grievances change the right from an incident of state citizenship to one of federal? Hague v. C.I.O.10 contains dieta to the effect that such a purpose does give rise to a federal right. The Cruikshank case, while holding that the right to assemble in and of itself is a right only of state citizenship, says in part:

21 Iogan 7. United States, 141 U.S. 263 (1892); although it does not include the right to be secure in person while in the custody of a gheriff, United States $\nabla$. Harris, see note 7, supra, unless the deprivation of rights is "under color of law" so as to invoke the Fourteenth Amend. ment, Screws จ. United States; 825 U.S. 91 (1945).

is In re Quarles and Butler, 158 U.S. 632 (1895).

2 Ex parte Yarborongh, 110 U.8. 651 (1884); but not gtate elections, for this is an element of gtate soverolgnty rather than national, so the deprivation mast have been under color of state law te give the Court Jurisdiction, Snewden ₹. Eughes, 821 U.S. 1 (1944).

21 Hague v. Congrews for Industrial Organizations, 307 U.S. 496 (1989).

I5 See note 6, supra.

18 See Sec. II, infra.

if See nete 6, supra.

16 Snowden 7. Hughes, 821 U.S. 1 (1944).

18 Sen note 14, supra. 
The right of the people peaceably to assemble for the purpose of petitioning Congress for a redress of grievances . . . is an attribute of national citizenship, and, as such, under the protection of, and guaranteed by, the United States. The very idea of a-government, republican in form, implies a right on the part of its citizens to meet peaceably for consultation in respect to public affairs and to petition for a redress of grievances. ${ }^{20}$

Thus, dicta from two cases, one of them very explicit, say that the right of which the plaintiffs claim to have been deprived is within that area of rights that Congress can protect against individual action. The argument seems sound, and there is no apparent reason why this is not as much a federal right as those protected in the cases applying sec. 241 of the Criminal Code. ${ }^{21}$ There being no contrary holding, it seems that this right is within the favored class.

\section{Intent of Congress As To Rights Covered and Power Exerted}

It is highly improbable that Congress could have intended that this statute ${ }^{22}$ apply only to state action. The subsection begins "If two or more persons . . . conspire", and thus makes no qualification that the persons must be exercising state powers, nor does it mention that the acts must be done under color of state law to come within its compass. This suggests that no such requirement was intended, especially since the immediately preceding section of the Civil Rights Act does apply only to state action, and requires in so many words that the deprivations be under color of law. ${ }^{23}$. A further indication of the intent of Congress is the phrase "for the purpose of preventing or hindering the constituted authorities of any State or Territory from giving . . . equal protection of the laws. ..." Congress scarcely intended

so See note 6, supra.

2 See notes 11-15, supra and text to which they refer.

- The revelant subsection is quoted in footnote 2 , as it appears in 8 U.S.C. sec. $47(3)$.

17 stat. 13, sec. 1, codified in 8 U.S.C. sec. 47 (2). 
to prohibit only the state from interfering with the "constituted authorities of any State" in its attempt to secure equal protection of the laws for all within the borders of the state; this phrase could have meaning only if it applies to individual action, and there is nothing in the subsection involved in the principal case to indicate that a different application was intended for it.

The dissenting judge in the principal case does not argue that Congress did not intend to authorize action against individuals-especially in the light of the then-prevailing idea among the legislators that the Fourteenth Amendment gave Congress power to protect the rights guaranteed therein against individual action-but he feels that, despite Congressional intent, Congress failed by the words of the statute to cover action other than that under color of state law.24 He argues that under the interpretation of the word "deprived" laid out in the Civil Rights Cases, an individual cannot deprive another of any rights unless he does so under the shield of state. authority, and that the most he can do on his own is to interfere with the enjoyment of that right, or commit a trespass or an assault, etc. The latter two being exclusively within the jurisdiction of the state courts and the first (interfering) not being within the wording of the statute, Judge Healy feels that no cause of action is maintainable in the federal courts. ${ }^{25}$

Aside from the argument based on the technical meaning of the word "deprived" when used in the statute, the majority opinion still was not as convincing as it might have been. The principal case is in direct conflict with decisions of the Eighth and Tenth Circuits, ${ }^{26}$ which hold that sec. 47 (3) authorizes suit for damages only where the deprivation of rights has been under color of law. Judge Orr in writing for the majority adverts to these two cases and their holdings, but.says that they (and apparently no other Appellate Court cases have construed this particular section,

^ See note 1, supra, p. 315.

sc Id., see quotation from Civil Rights Cases at page 316.

* Iope X. Chandler, 124 F.2d 785 (8th Cir. 1942); Vlles V. Symes, 129 F.2d 828 (10th Cir. 1942); see also Bomar v. Bogart, 159 F.2d 338 (2d Clr. 1947). 
certainly none have reached the Supreme Court) ${ }^{27}$ were decided erroneously. He argues that the construction placed on the section in these decisions is contrary to that which the Supreme Court placed on "similar wording" in the Harris case, ${ }^{28}$ thus placing himself in the anomalous position of supporting his construction with a case which held that the "similar" statute there construed was unconstitutional. The Harris holding, however, does answer the argument of the dissent in the principal case that the use of the word "deprive" makes it impossible for individuals not acting under color of the law to come within the wording of sec. 47 (3), since the statute there held to be unconstitutional-because it purported to punish individuals for depriving citizens of rights guaranteed only by the Fourteenth Amendment-also used the word "deprived."29

In view of the apparent intent of Congress, and the decision in the Harris case, which seems to answer Judge Healy's argument, it seems fairly certain that the statute in terms applies to individual action. Whether or not the statute should be declared unconstitutional within the reasoning of the Harris case will be discussed later..$^{30}$

Although it is apparent that Congress intended to cover individual action, it would seem equally apparent that Congress intended to exercise the powers granted by section 5 of the Fourteenth Amendment. The original statute from which sec. 47 (3) was taken was entitled "An Act to Enforce The Fourteenth Amendment," though it is more commonly known as the "Civil Rights Act of 1871," 17 Stat. 13. The wording of the statute itself in many places fairly closely follows that of the Amendment.

2 Robeson v. Fanelli, 19 L.W. 2237 (S.D.N.Y., Nov. 10, 1950), cites the Hardyman case and offers dictum to the effect that the right to assemble may be protected by Congress if the assembly is only to discuss national affairs. This would seem to extend the Hardyman doctrine, but it remains dictum, since the case was decided on other grounds. The Court specifically refused to decide whether or not individuals were capable of depriving citizens of their rights, viz., one of the main points of the dissenter's argument in the Hardyman case.

28 See note 7, supra.

* Revised Statutes, sec. 5519.

so The Harris case held the statute there construed to be unconstitutional because it covered rights that Congress lacked power to protect against individual action, and the provisions were inseparable. 
Of course the constitutional authority under which Congress sought to act is irrevelant in passing on the validity of the statute, since the statute will stand if Congress has any power which would support it. As Justice Douglas said in Woods v. Miller Co., "The question of the constitutionality of action taken by Congress does not depend on recitals of the powers which it undertakes to exercise."s1 However, the power Congress intended to exercise does become relevant in determining the scope of the statute. While in some instances, the words of a statute may be narrowed by a recital of the power under which Congress purported to act, here they seem to be broadened.

The Supreme Court's conclusion in the Harris case that another provision in the same section of the Civil Rights Act covered all Fourteenth Amendment rights-and covered them against individual action-led to that provision's being declared unconstitutional. Therefore, it is hard to argue that Fourteenth Amendment rights are not covered by the "similar" damages provision of the same section. Moreover, the clause "whereby another is injured in his person or property," which appears in the damages provision-the provision construed in the principal caseseems to go far beyond those rights held to be essential to the maintenanco of a republican form of government.

The section requires that the deprivation result from acts done "in the furtherance of conspiracy set forth in this section." Among the conspiracies specified ${ }^{32}$ is one to deprive any person "of the equal protection of the laws, or of equal privileges and immunities under the laws." Thus the conspiracy requirement of the damages section would seem to be fulfilled by $a$ conspiracy to deprive persons of rights guaranteed only by the Fourteenth Amendment; and so some provisions in this section clearly seem unconstitutional.

al Woods v. Miller Company, 333 U.S. 138 (1948), at page 144.

* The section also mentions a conspiracy to injure anyone entitled to vote, in person or property, because of advocacy of a candidate for Presidential Elector or Congressman, so it is arguable that this con. spitacy is required to satisfy the conspiracy requirament of the dam. ages section. 


\section{Severability}

The only way to uphold the principal case would seem to be by application of the doctrine of separability. The alternative of supporting the statute under the Fourteenth Amendment is precluded by a long line of cases establishing the proposition that the Fourteenth Amendment only prohibits state action-however liberally that doctrine of state action is construed.83

What test should be applied as to separability? Every attempt of the Court and writers to formulate a rule has failed. United States v. Reese stated that the Court could eliminate portions of a statute that were unconstitutional and save the rest under certain circumstances; but the holding was that broad language, including both rights within the power of Congress to protect and rights which were not within such power, could not be limited so as to include only the unobjectionable part, the entire statute therefore being invalid. ${ }^{34}$ The Harris case, following this proposition, invalidated in toto section 5519 of the Revised Statutes (also a provision of the Civil Rights Act of 1871) because the penalties were imposed for deprivation of rights-for conspiracy, and action in furtherance of that conspiracy, to deprive "any person or class of persons of the equal protection of the laws, or of equal privileges and immunities ... ."-which could not constitutionally be protected against action not under color of law. The Court refused to limit the statute to those rights which Congress could validly protect. Among its reasons the Court suggested that in a criminal statute the offense must be outlined specifically; a clarification by judicial decision-necessarily retroactive-would not conform to this policy of adequate notice of the limits of the crime. On the other hand, a 1912 decision interpreted a regulatory statute prohibiting sale of certain sponges anywhere in the United States as applying only to sponges involved in interstate commerce, and thus,

\footnotetext{
4 This is true even though the Fourteenth Amendment is capable of being construed so as not to require state action, if it were an original question. See: Flack, Adoption of the Fourteenth Amendment (1908).

w United States r. Reese, 92 U.S. 214 (1875).
} 
by astute judicial construction, preserved the constitutionality of the statute.85

An exhaustive treatment of separability is offered by Stern, who writes:

“. . the invalidity of part of a law or of some of its applications will not affect the remainder (1) if the valid provisions or applications are capable of being given legal effect standing alone, and (2) if the legislature would have intended them to stand with the invalid provisions stricken out." ${ }^{38}$

"The test for severability clearly must be whether the legislature would have intended the valid parts or applications of a statute to stand if it had known when the law was enacted of the invalidity of the remainder."33

Under this test the question is whether Congress would have passed the section. here under consideration had it known at the time that it lacked the power to protect from individual action the rights. which, under the Fourteenth Amendment, may be protected from state action. The answer seems obvious. Accordingly, under this test as to separability, the statute, so far as it is involved in the principal case, is constitutional-a result effectuating the intent of Congress in passing the Civil Rights Act to protect such rights against deprivation from any source and to cover the field as far as possible.

The provisions here in question do not, so much as penal statutes, fall within the policy insisting on specific notice of the acts creating liability. Moreover, they do not come within the holding of the Reese and Harris cases, since here severability of the unconstitutional portions can be easily accomplished by deleting the clause "whereby another is injured in person or proporty." The portion of the section applied in Hardyman v. Collins, "deprived of having and exercising any right or privilege of a citizen of the United States," has already been limited by Congress to an area where Congressional power exists. Therefore, Congress

* The Abbey Dodge, 223 U.S. 166 (1912).

* Stern, Beparabitity and Beparabitity Olauses in the Bupreme Oourt, 51 Harvará L. Rev. 76. See also, Dorchy v. Kansas, 264 U.S. 286 (1924).

1 I d. page 98. 
has validly exercised this power to protect rights necessary to the existence of a republican form of government, a power conferred by the "necessary and proper" clause of Art. I, sec. 8 of the Constitution.

\section{Conclusion}

There exists a narrow area of rights "inherent in national citizenship" because they are necessary for the efficient operation of a republican form of government; these rights Congress has the power to protect against action by individuals. Among these rights is that of assembly for the purpose of petitioning Congress for a redress of grievances.

When Congress passed the Civil Rights Act, it intended to authorize an action for damages against individuals who had deprived citizens of their rights as citizens of the United States. Although Congress also intended to protect rights which it lacks power to protect against individual action, the portion of the statute utilized in the principal case is valid, as the provisions are severable.

As to policy factors, Judge Healy, in his dissent, seems to be unduly alarmed over the prospect that the federal courts will be packed with cases that he feels should be left to the states. Of course, already one case has, by way of dicta, extended the rights necessary to a republican form of government to include the right to assemble to discuss national affairs, on the ground that such assembly is a preliminary to formulation of petitions for redress of grievances. ${ }^{38}$ Theoretically, the' idea of rights essential to a republican government could be extended to include almost all personal rights, a development that would parallel the amplification -also in theory almost illimitable ${ }^{38}$ - of state action for purposes of the Fourteenth Amendment. Several wellestablished authorities, however, seem to preclude such an extension. Therefore, affirmance of the Hardyman $v$. Col lins decision would probably bring about only a slight increase in litigation, a few suits by persons who either would be hesitant to press criminal charges, or who wish compen-

$\approx$ See note 27, supra.

* Cf. Shelley v. Kraemer, 334 U.S. 1 (1948). 
sation as well as the gratification of a successful prosecution. Yet, who can say that these additional suits would be unhealthy? And perhaps they might produce a more complete enforcement of section 241 of the Criminal Code, as well as provide a federal remedy for this type of wrong (pessibly not needed so much in Los Angeles County as in other places ${ }^{40}$ ) where, as in many instances, all state remedies are inadequate.

\section{JAMES E. THOMPSON.}

* Hardyman 7. Collins, see note 1, supra, at page 319, dissenting opinion. The "incident occurred in La Crescenta, a sizeable suburb of the City of Los Angelea. One hardiy need gay that the Ios Angeles community is justly celebrated for its tolerance of all sorts and con. ditions of people and ideas. The hospitality of the community embraces not merely the conformist, the respectable and the truly good, but the proponents of practically every fom under the sun." 